\title{
MARIA BANDEIRA, AN ELUSIVE BRAZILIAN BOTANIST ${ }^{1}$
}

\author{
Tarciso S. Filgueiras ${ }^{2}$, Ariane Luna Peixoto \& Begonha Bediaga
}

\begin{abstract}
Maria do Carmo Vaughan Bandeira (1902-1992) is a little-known Brazilian botanist who worked for about ten years at the Botanical Garden in Rio de Janeiro, Brazil. She made approximately 800 botanical collections, including mosses (her special interest) but also lichens, fungi and occasionally angiosperms. She studied at La Sorbonne in Paris, corresponded with leading botanists in different fields of botanical research in Europe and the USA, and represented the Rio de Janeiro Botanical Garden in many instances. At age 29 she abandoned a promising research career and entered a convent in Rio where she lived for 60 years as a cloistered nun.
\end{abstract}

Key words: herbarium, fungi, lichens, mosses, women in botany

Tarciso S. Filgueiras, Instituto de Botânica, Secretaria do Meio do Meio Ambiente do Estado de São Paulo, Avenida Miguel Stefano 3687, Água Funda, São Paulo, SP, CEP: 04301-902, Brazil; e-mail: tfilg@uol.com.br

Ariane Luna Peixoto \& Begonha Bediaga, Instituto de Pesquisas Jardim Botânico do Rio de Janeiro, Rua Pacheco Leão 915 , Horto, Rio de Janeiro. RJ, CEP: 22460-030,Brazil; e-mail: ariane@jbrj.gov.br \& begonha@jbrj.gov.br

\section{MARIA BANDEIRA, AN ELUSIVE BRAZILIAN BOTANIST}

Our interest in Maria Bandeira started about two years ago when the senior author, an agrostologist by profession, stumbled on the following statement in Pamela Henson's (2003) paper discussing a trip that the American agrostologist Agnes Chase (1869-1963) took to Brazil in 1924: 'Doña Maria Bandeira was a moss specialist at the Botanical Garden in Rio de Janeiro, who went out of her way to facilitate Chase's work and even accompanied Chase on her field trips several times' (Henson 2003: 445).

Intrigued, we began our search because we simply had no inkling of who Maria Bandeira was. Our search began at the Botanical Garden in Rio de Janeiro, where Bandeira was said to have worked. To our surprise, only a handful of Brazilian bryologists had previously heard of that name. However, in the Garden's registration book it is recorded that on 5 June 1925 she was hired as a trabalhador de $1^{a}$ classe (grade-one worker). We then turned to other governmental sources. A ministerial report of 1927 from the

\footnotetext{
1 Invited paper

2 Corresponding author
}

Ministry of Agriculture, Industry and Commerce published a note stating that 'Senhorita Maria do Carmo V. Bandeira' had carried out studies of the mosses and fungi of Brazil, that she had incorporated over 500 species into the herbarium, that she had made botanical excursions in the State of Rio de Janeiro, and that she had exchanged botanical specimens with botanists in Brazil (State of Bahia) as well as in Germany (Jena), Finland (Helsingfords), the United States of America (New York) and Austria (Vienna) (Castro 1929: 89).

Finally, the Diario Official (a vehicle for legal documents issued by the federal government in Brazil) of 19 April 1928 published a contract showing that Bandeira was hired as a botanist, a 'specialist on plant systematics', to work at the Botanical Garden in Rio de Janeiro for the period of three years (Brazil 1928: 10120).

Through these official records we could confirm that Bandeira indeed existed. But who was this person? Was she still alive? If so, where was she? What else had she done besides what was recorded in governmental sources? At this point we had many questions and almost no answers. 


\section{OTHER SOURCES}

Henson's paper brought yet another important clue. According to her, in 1931 Bandeira gave up her job and entered a convent. That was a great disappointment to Chase, who saw Bandeira as a promising young scientist and a close collaborator. This also puzzled us a great deal. We wondered, why would a person at the outset of a promising career leave a job and enter a convent?

The next problem we faced was to find out which convent Bandeira had chosen, amongst a handful of possibilities. Intuition led us to the gates of the oldest convent of cloistered nuns in the city of Rio de Janeiro, the venerable Carmelite Convent of Santa Teresa, located on the top of a hill. Our intuition did not fail us. After some anxious moments in the somber parlor (a small visiting area in the convent), suddenly a curtain opened from the inside and three nuns materialized before our astonished eyes: the mother superior and two other sisters. A wall about one meter high topped by iron bars separated us. The nuns seemed meek, calm but formal. They were the only members of the community we ever saw. The good mothers informed us that Sister Maria do Carmo (Bandeira) had been one of them for 60 years. They provided us with invaluable information on Bandeira's convent life and even gave us the means to contact a member of her immediate family in the city of Rio de Janeiro.

We then proceeded to gather as much information as possible about our subject. We contacted librarians and archivists from several institutions in Europe and in the United States, trying to locate letters, photos and other documents related to Bandeira. Meanwhile, we started searching for possible scientific papers she might had published. We found none. The search for specimens collected by Bandeira led us to consult two important data banks, Jabot (http://www.jbrj.gov.br/jabot) and SpeciesLink (http://splink.cria.org.br), and the literature dealing with moss taxonomy. We also searched the Rio de Janeiro Botanical Garden's herbarium. We had three informal meetings with members of the Bandeira family: Marina Bandeira and João Bandeira de Freitas, niece and grand- nephew of Maria Bandeira, respectively. These encounters were quite fruitful. Bandeira's relatives received us with open arms and helped us in every way possible. They provided us with letters, photos and important anecdotal information about our subject.

An account of our findings about Bandeira's life and her professional accomplishments is in preparation (Bediaga et al., in prep.). Nonetheless, we felt that a complementary note would be welcomed by the general reader interested in the history of botany in Brazil. This is what we intend to present here.

\section{WhO WAS MARIA BANDEIRA?}

Maria do Carmo Vaughan Bandeira was born in Rio de Janeiro in 1902 and died in the same city in 1992. She was the youngest child of an upper middle class family with five children (four girls, one boy). Her father was a medical doctor with important social connections. After finishing her secondary education she decided she wanted to study botany. The obvious choice was the Botanical Garden in Rio de Janeiro, where a team of mostly self-educated men carried out important botanical research. Bandeira's father was a friend of Antônio Pacheco Leão (1872-1931), also a medical doctor as well as a botanist, who was then director of the Rio de Janeiro Botanical Garden. Through the influence of this man, Bandeira became associated with the Botanical Garden - as a kind of trainee, from what we gathered.

Apparently Bandeira made a good impression in that male-dominated environment because she quickly evolved from doing purely clerical work (organizing herbarium cards, filing herbarium specimens, etc.) and started actively collecting botanical specimens, especially mosses, fungi and lichens, but also flowering plants. She also started writing letters, contacting important scholars in different parts of the world and exchanging botanical material with them.

Most certainly Bandeira was a very intelligent individual. Her linguistic skills were remarkable and quite unexpected in a Brazilian woman of that time. Besides Portuguese, her native tongue, 
she was fluent in English (she studied in England for many years), French (she studied at the Sacré Coeur de Jésus, a prestigious Catholic school in Rio), German, and was also proficient in Latin, this undoubtedly a good asset for any young aspiring plant taxonomist at that time. A few years later, while traveling in Italy, she wrote home saying that she found herself speaking Italian ${ }^{3}$. At the Vatican, a Swiss guard told her in German that she could easily pass as a German girl. This linguistic ability certainly helped to open many doors to Bandeira, both in Brazil and abroad.

Upon getting involved in research projects at the Garden, apparently Bandeira was encouraged to take up the study of mosses, fungi and lichens, but it appears that she favored the mosses. She started collecting in several localities throughout the states of Rio de Janeiro and Minas Gerais. Pretty soon she was corresponding with one of the most prestigious moss specialists of the time, Viktor F. Brotherus (1849-1929). She sent him specimens for identification, but before doing so she tentatively identified them herself (Figs $1 \& 2$ ). Brotherus acted as mentor, providing bibliographic information and encouragement. Apparently he was very pleased with the partnership; he even expressed his intention to honor Bandeira with the epithet of a new moss species she had collected and that he intended to describe ${ }^{4}$.

Agnes Chase and Bandeira became good friends and collaborators. Bandeira accompanied her on two collecting trips in Brazil and they were photographed together on several occasions, including a trip to Pico de Itatiaia (Fig. 3), a high mountain top in the State of Rio de Janeiro, where the Garden had established a field research station which later became a national park. Chase encouraged Bandeira to go to Europe and seek higher education ${ }^{5}$. She even wrote letters of introduction

\footnotetext{
3 Letter from M. Bandeira to Nelita and Mario, Rome, 25 Jun. 1930. Private archive of the Bandeira family, Rio de Janeiro, Brazil.

4 Letter from V. F. Brotherus to M. Bandeira, 2 Dec. 1926. Archives, University of Helsinki, Finland.

5 Letter from A. Chase to M. Bandeira, Washington, 29 Jan. 1931. Smithsonian Institution Archives, Collection no. 229, Box 1, Folder: Bandeira, M. C.
}

presenting Bandeira to leading European botanists. Bandeira later wrote to Chase acknowledging that the letters had been very helpful ${ }^{6}$.

During her years working at the Garden she showed a clear interest in the employees' children. When she learned that most of them had never seen the Atlantic Ocean just a few kilometers away, she took them in her own car for a picnic at the beach. According to family members, she often went swimming at the beach, where she made friends among the local fishermen.

\section{EUROPEAN TOUR AND STUDIES IN PARIS}

In early 1930 Bandeira went on a trip to Europe, where she visited several places in Italy, Switzerland, Austria, England and France, but her final destination was Paris. In Paris, later that year, she began to study 'moss protoplasm' under the guidance of Louis E. Lapicque (1866-1952) at the Sorbonne. She had met Lapicque years before in Rio, during one of his visits to the Botanical Garden where he had carried out experiments with the sensitive plant (Mimosa sensitiva, treated as Mimosa veloziana at the time). Lapicque was a physiologist of enormous prestige in France and other European countries, as well as in Brazil where he had many professional contacts. When he visited Rio in 1927 he was received with honors and was elected corresponding member of the Brazilian Academy of Science (Petitjean 2001). Besides science, Lapicque had a strong interest in social justice; he was involved with social and political causes to the extent that he was considered a savant concerné who had connections with the gauche socialiste in France (Trebitsch 1995).

While under Lapicque's guidance, Bandeira lived in a boarding house with other female Sorbonne students and a few female high school teachers. Her letters of the period indicate that she was quite happy then. Working at the lab in the Sorbonne was almost like a dream, she wrote.

\footnotetext{
6 Letters from M. Bandeira to A. Chase, Paris, 8 Jan. 1931. Smithsonian Institution Archives. Collection number 229, Box 1, Folder: Bandeira, M. C.
} 


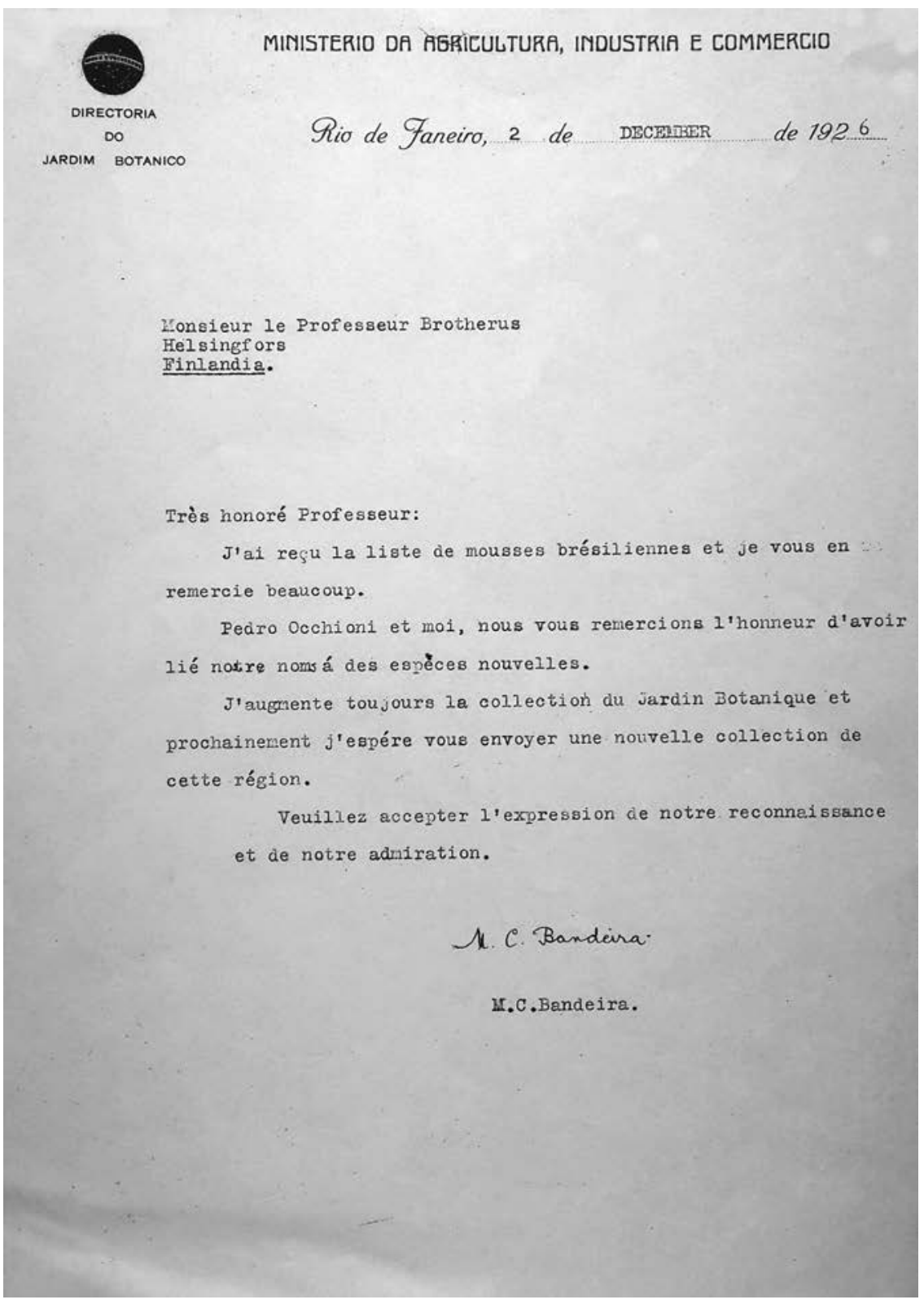

Fig. 1. Letter from Maria Bandeira to Viktor F. Brotherus, 2 December 1926 (Archives of University of Helsinki, Finland).

She also enjoyed the company of her colleagues and the general atmosphere of the boarding house, where there was even a gramophone! At this time she started experimenting with cooking and dishwashing because they had no help at the boarding house. She seemed perfectly content:
Realmente, nada tenho a desejar ('Really, there is nothing else I desire') ${ }^{7}$.

7 Letters from M. Bandeira to Mario and Nelita, Paris, 30 Nov. 1930. Private archive of the Bandeira family, Rio de Janeiro, Brazil. 


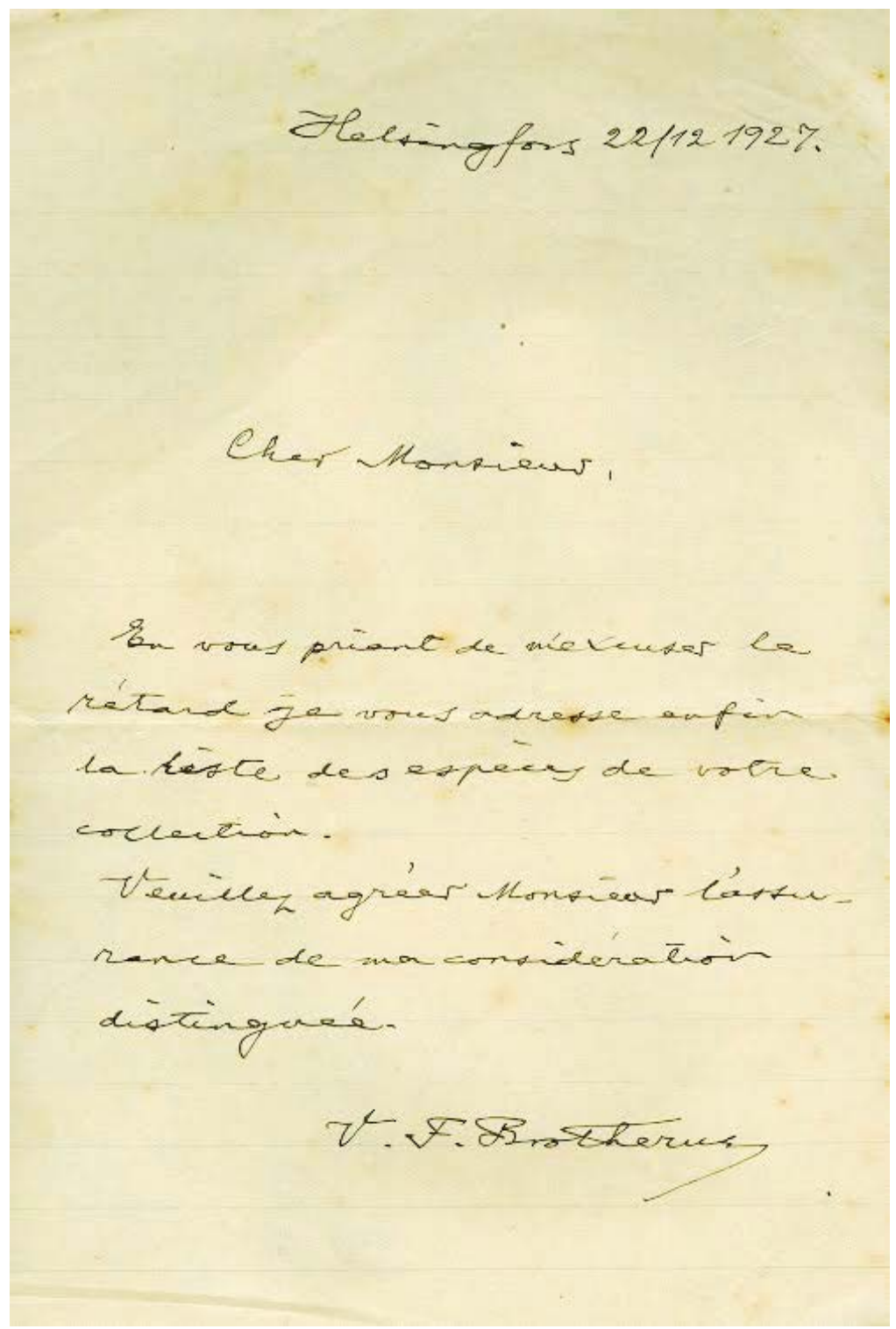

Fig. 2. Letter from Viktor F. Brotherus to Maria Bandeira, 22 December 1927 (Private archive of Bandeira family, Rio, Brazil).

On 8 January 1931 she wrote in a letter to Agnes Chase: 'I shall remain here [at the Sorbone] until I finish the work I am preparing under Prof. Lapicque's guidance and which will enable me to a Diplôme d'études superieures. I am also following courses in Physical Geography'. She had plans for the future: 'I am simply dying to apply all the knowledge on the subject [Physical Geog- raphy] so as to explain the Itatiaia, Pão de Açúcar, etc., and all the formations in Brasil' ${ }^{8}$.

We were unable to determine whether Bandeira finished this particular research project on 'moss

8 Letter from M. Bandeira to Mario and Nelita, Paris, 3 Jan. 1931. Private archive of the Bandeira family, Rio de Janeiro, Brazil. 


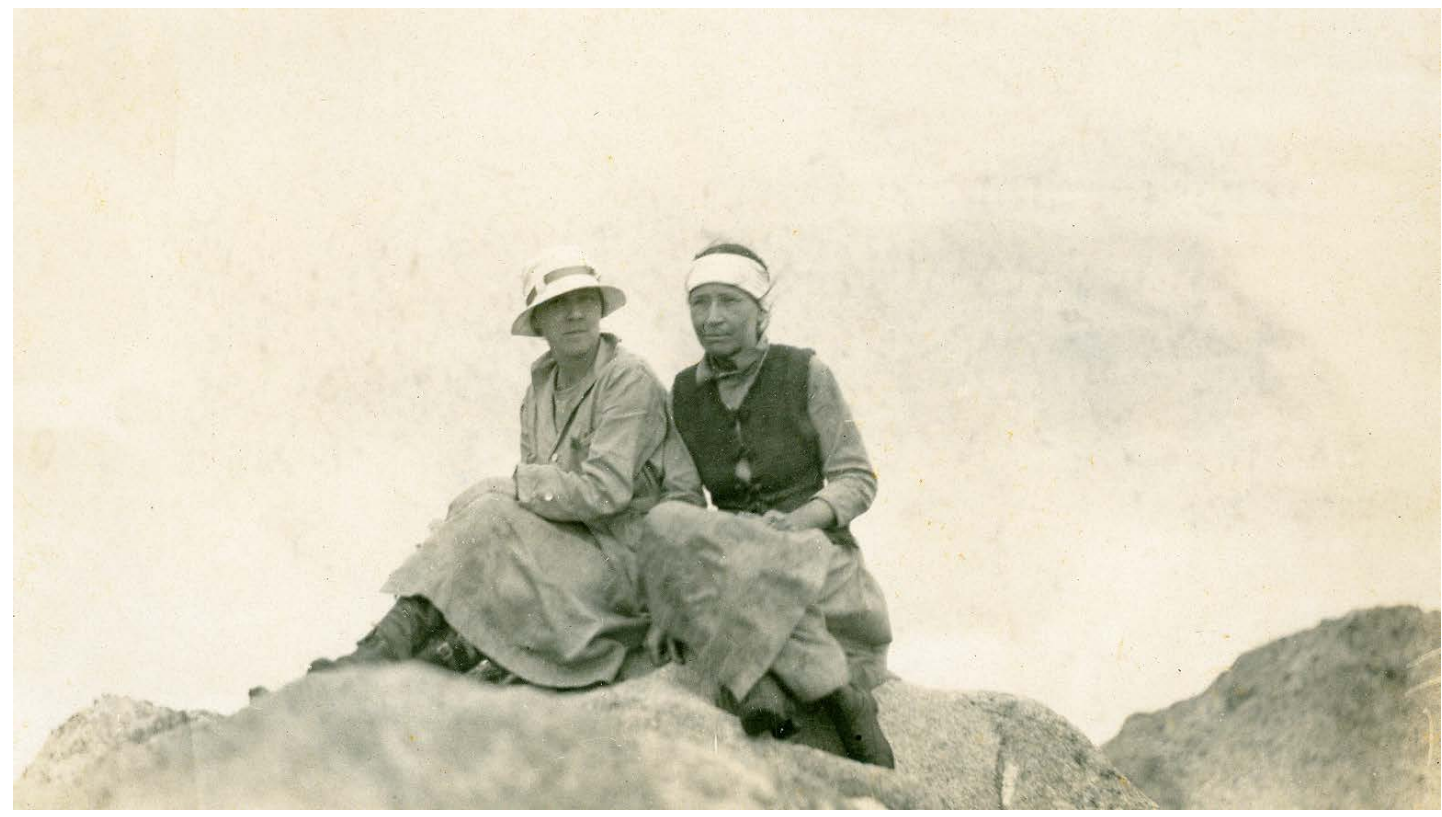

Fig. 3. Agnes Chase (right) and Maria Bandeira (left) at Pico das Agulhas Negras, Itatiaia, State of Rio de Janeiro, 17 January 1925 (Private archive of Bandeira family, Rio, Brazil).

protoplasm'; neither could we determine the exact nature of the project, nor could we find out whether she got her intended degree. And it is not clear whether she was working as an assistant to Lapicque and at the same time pursuing a degree, but in a letter she calls him Patron (boss). It is important to emphasize that Bandeira was part of an extensive network of women scientists who supported each other with advice, logistics, hospitality and encouragement (Henson 2003: 44). Besides Agnes Chase, Bandeira also corresponded with and sent grass specimens to the British botanist Agnes Arber (1879-1960), one of the most eminent plant morphologists and anatomists of her time.

\section{ROYAL CONNECTIONS AND FRIENDS}

Some documents to which we had access show that Bandeira counted persons with noble titles among her selected friends (Fig. 4). For example, in 1927, Dom Pedro de Orléans e Bragança, a grandson of the dethroned emperor of Brazil, invited her to visit him and his wife in their family home in Petrópolis, State of Rio de Janeiro, and also suggested that while there she could undertake a field excursion to collect mosses ${ }^{9}$. In April 1930, while Bandeira was in Paris and the Orléans e Bragança were in the family castle in d'Eu in the interior of France, Bandeira had lunch with the prince in Paris and later His Highness invited her for a weekend in the castle ${ }^{10}$. His wife, Princess Elisabeth Dobrzenicz de Orléans e Bragança, addressed her in a note as her 'good little friend'. This is probably why Bandeira told her family in a letter that de Orleans e Bragança had been 'very kind to me'.

In Fribourg, Switzerland, the Baroness of Montenach invited her for lunch and took her along to spend the day in her country home ${ }^{11}$. On another

\footnotetext{
9 Letter from P. O. Bragança to M. Bandeira, Petrópolis, 30 Mar. 1927. Private archive of the Bandeira family, Rio de Janeiro, Brazil.

${ }^{10}$ Letter from P. O. Bragança to M. Bandeira, Paris, 29 Oct. 1930. Private archive of the Bandeira family, Rio de Janeiro, Brazil.

${ }^{11}$ Letter from M. Bandeira to Nelita and Mario, Chamonix, 27 Aug. 1930. Private archive of the Bandeira family, Rio de Janeiro, Brazil.
} 
occasion, during the $8^{\text {th }}$ Congress of the Unione Internazionale delle Leghe femminili Cattoliche in Basel, Switzerland, a certain Marchese Maddalena Patrici Gondi sent Bandeira a written invitation for una tazza di thé at her home. No wonder Bandeira remarked in a letter to her family that the Basel congress was attended by many princesses, countesses and baronesses ${ }^{12}$.

When she was living in the boarding house in Paris, a certain Mrs. Keay (apparently a friend of the family), who happened to be visiting the city, wrote her saying she wanted to see her. They had dinner at the Hotel Continental, 'one of the most elegant hotels in Paris', she wrote home on 30 November 1930.

During her visit to Rome she attended several canonizations in the Piazza of Saint Peter in the Vatican, a few in the company of members of the Italian aristocracy. She declared she had seen the Pope nine times and had kissed his ring three times. In Geneva she visited the Botanical Garden and met the director, Prof. Robert Hippolyte Chodat (1865-1934), a famous Swiss botanist who had worked in Paraguay. After a long conversation in French, Chodat took her for an automobile ride in the company of his sister, and later they had tea at his home ${ }^{13}$.

While in Paris, besides working in Lapicque's laboratory, Bandeira also acted as secretary to the Comissão de Cooperação Intelectual, which was then part of the United Nations. The meetings were held at the Palais Royal ${ }^{14}$.

The episodes just described strongly suggest that Bandeira was well connected. Therefore it is entirely possible that her friendship with titled persons and her association with persons in high places were helpful in certain circumstances while

\footnotetext{
12 Letter from M. Bandeira to Nelita and Mario, Chamonix, 27 Aug. 1930. Private archive of the Bandeira family, Rio de Janeiro, Brazil.

${ }^{13}$ Letter from M. Bandeira to Nelita and Mario, Chamonix, 27 Aug. 1930. Private archive of the Bandeira family, Rio de Janeiro, Brazil.

${ }^{14}$ Letter from M. Bandeira to Mario and Nelita, Paris. 3 Jan. 1931. Private archive of the Bandeira family, Rio de Janeiro, Brazil.
}

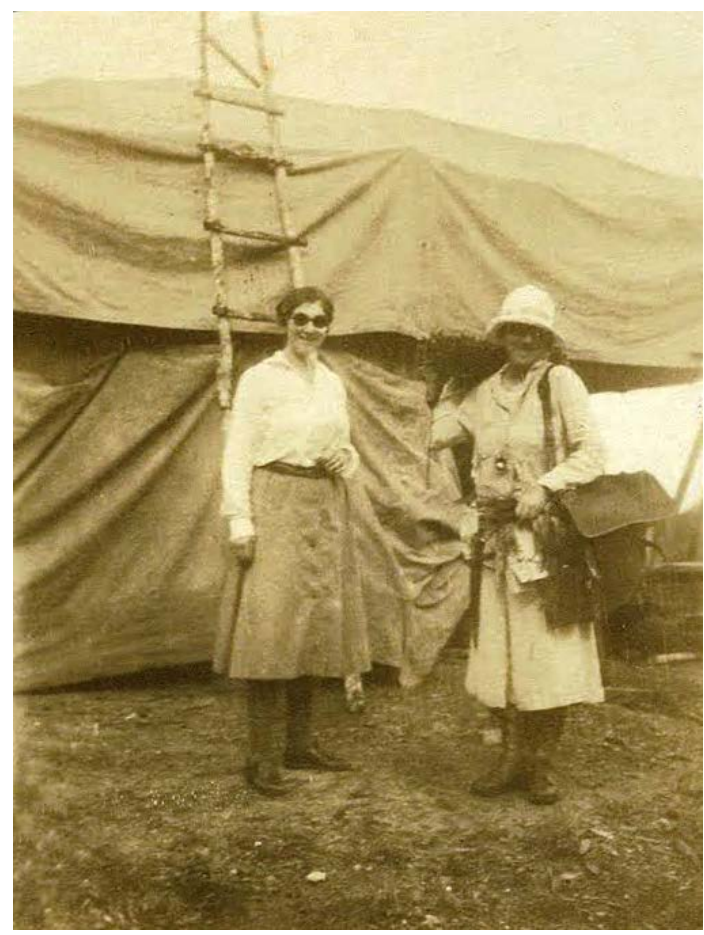

Fig. 4. Maria Bandeira (left) and Princess Elizabeth de Orléans e Bragança (right) at Parque Nacional de Itatiaia, Rio de Janeiro, 1920s (Private archive of Bandeira family, Rio, Brazil).

she was in Europe, especially when she was living in Paris.

Bandeira also had a famous cousin, Manuel Bandeira (1886-1968) one of Brazil's greatest poets.

\section{A LETTER FROM THE CONVENT, AND RETURN TO RIO}

Apparently, all was going well with her studies at the Sorbonne. She had a new microscope. Professor Lapicque and his wife treated her like a daughter ${ }^{15}$. Things begin to change rapidly somewhere during the year 1931, when she received a letter from the mother superior of the Santa Teresa Convent. In the letter, Mother Maria José de Jesus (Honorina de Abreu, 1882-1959, daughter of Capistrano de

\footnotetext{
${ }^{15}$ Letters from M. Bandeira to Mario and Nelita, Paris, 30 Nov. 1930. Private archive of the Bandeira family, Rio de Janeiro, Brazil.
} 
Abreu, a famous Brazilian historian) informed her that the long-awaited 'opening' at the convent was finally available and that if she really wanted it she was to return to Rio at once. She did. Later that year she entered the convent and her 'public' life ended at that time. We have found no record of Lapicque's reaction to Bandeira's return to Brazil.

This sudden departure from her career plans suggests that Bandeira's decision to enter a convent was not really a hasty one. She may have been brooding over it for some time, preparing herself for the occasion, and at the same time waiting for an opening at the convent, which can only take a maximum of twenty nuns at one time ${ }^{16}$.

\section{ENTER A CONVENT? WHY?}

We have no solid grounds upon which to speculate on the motives that led Bandeira to take this unexpected route in life, and we simply refuse to issue idle speculations. Nevertheless, it is perhaps appropriate to contextualize her decision. For example, her beloved parents had both died, and so had Pacheco Leão and Brotherus. After the death of the parents, the Bandeira siblings were having animated discussions about their inheritance. This was very distressing to her and, to top it off, her three-year contract at the Garden had terminated. On the other hand, it is important to bear in mind that Bandeira belonged to a deeply religious Catholic family. Two of her three sisters had already entered the Sacré Coeur de Jésus Convent in Rio. We should also emphasize that at that time the Catholic world was strongly moved by the canonization of Thérèse of Lisieux (Saint Thérèse of the Child Jesus and of the Holy Face) in 1925. Saint Thérèse, the 'Little Flower', was a cloistered Carmelite nun who entered the convent when she was only 15 years old and died of consumption at 24 years of age. Her autobiographical book The Story of a Soul, published just one year after her death, sent mystical waves throughout

\footnotetext{
${ }^{16}$ Regra e Constituiçőes das Religiosas Descalças da Ordem da Gloriosíssima. Virgem Maria do Monte Carmelo, Rio de Janeiro, Gráfica Mendes Jr. Tradução do original italiano por Madre Maria José de Jesus. 1930.
}

the Catholic world and probably Bandeira was quite aware of this.

Nevertheless, her family was astonished when she announced her decision to enter a contemplative convent of cloistered nuns. That revelation did not cut any ice even with her closest sister Helena (nicknamed Nelita), in whose home she was living then. According to a family source, Adolfo Ducke (1876-1959), a colleague and mentor at the Garden, was 'furious' when he heard of Bandeira's intention.

At the end, Bandeira's decision prevailed. On 11 April 1932 she was solemnly received into the cloister of the convent, dressed as a bride, as was the custom of the time. She received the religious name of Ir. (Sister) Maria do Carmo de Cristo Rei. She pronounced her simple vows in the following year and the perpetual vows ('solemn vows') in 1938. She remained in the convent for sixty years, living in complete seclusion, dedicating herself to prayer, silence and religious studies. According to the nuns we talked with, she occasionally brought up the topic of mosses and other plants in conversation. Surely a faint echo of a past she had renounced completely.

\section{Convent LiFe}

She was described by the nuns we met as possessing a witty and vibrant personality, and as being studious, deeply involved with Carmelite values and spirituality; at the same time, she enjoyed long solitary walks inside the convent enclosure. During all her years in the convent she never lost contact with her relatives. She often wrote letters expressing a preoccupation with their well-being and also received occasional visits (Fig. 5).

A woman of many talents, during her prime years Bandeira dedicated much effort to cataloguing and curating the innumerable artistic assets found in the convent. She also held the post of clavária (member of the convent council) and for a long time was nurse to an elderly nun. For many years she worked closely with Mother Maria José de Jesus, who translated the complete works of Saint Theresa of Avila to Portuguese. On 3 August 


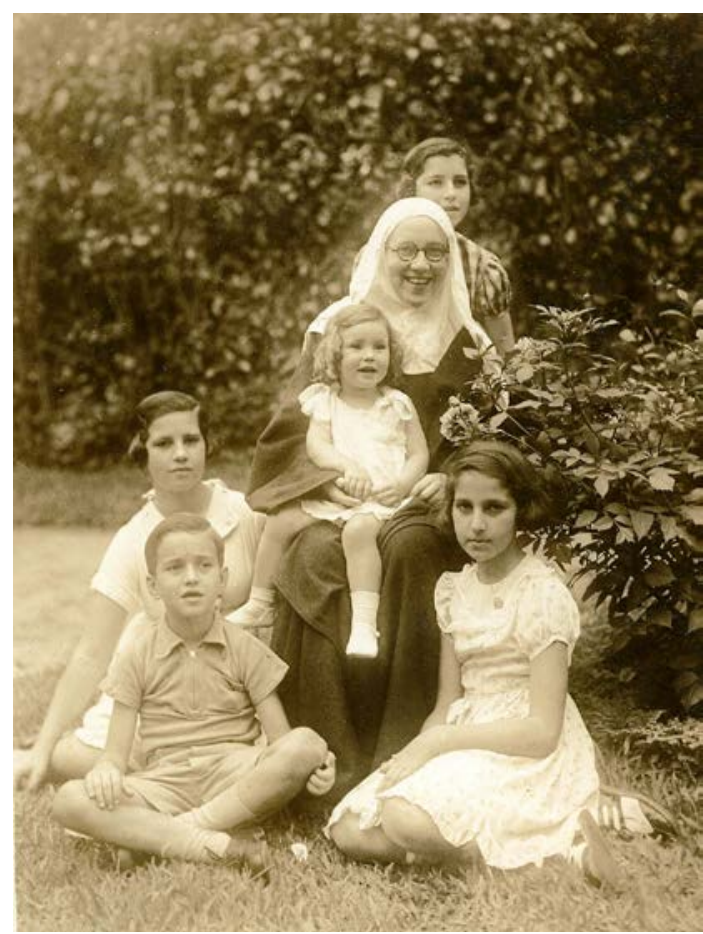

Fig. 5. Maria Bandeira (Sister Maria do Carmo de Cristo Rei) photographed in the company of her nieces and nephew in a Rio de Janeiro hospital, when she was recovering from an illness. 1935 (Private archive of Bandeira family, Rio, Brazil).

1956, de Jesus acknowledged this fact candidly in a letter to Sister Maria de Lourdes from the convent of Santíssima Trindade: Terminei a tradução das Cartas de Nossa Santa Madre, ajudada por Ir. Maria do Carmo, que trabalha mais do que eu ('I have finished the translation of the Cartas [Letters] by our Blessed Mother with the help of Sister Maria do Carmo, who works [even] more than I do'; after Gallian 1997).

Bandeira also played an important role in the rejuvenation of the old convent building, built in 1750. For that she enlisted the help of her grandnephew, João Bandeira de Freitas. In her later years, the good nuns informed us, she took up the study of the Greek and Hebrew languages because she wanted to be able to read the sacred scriptures in the 'original'. While waiting in the queue to enter the church for the daily community prayers, five times a day, she was always seen with a dictionary in her hands. She had the soul of a scholar but very little talent for the art of embroidery, the nuns told us.

She never left the convent, not even after her death. She died of natural causes at age 90 and is buried in a simple grave in the convent cemetery, as is the custom in the order.

From a purely laic perspective, Bandeira's decision to interrupt a promising scientific career to enter the convent of a monastic order is doubly provocative. Firstly because she had the ability to become a real scientist in her own right and possibly to get a research or teaching position at a respected institution. Secondly, she could have chosen a more flexible order where very likely she could have continued pursuing her scientific endeavors. Her decision was rather a radical one; she opted for one of the strictest orders in the Catholic Church, the Order of the Discalced Carmelites.

While still in Europe, Bandeira wrote several letters to her family. Some were written just before she left Paris to return to Rio and enter the convent. In these letters we found no clue that something of an extraordinary nature was about to happen to her. Apparently she kept her decision secret. Perhaps, being naturally of a shy disposition, she did not want to advertise her inner decision, choosing not to make it widely known.

\section{BANDEIRA THE BOTANIST}

Bandeira's material legacy to botany is represented by important historical collections of mosses, lichens and fungi gathered during the 1920s and housed in the herbarium of the Rio de Janeiro Botancial Garden (RB), with duplicates in several herbaria elsewhere in the world. She made around 800 botanical collections, the vast majority of which appear in the taxonomic literature (e.g., Vattimo-Gil \& Vattimo 1980; Yano 1984; LuiziPonzo \& Barth 1999; Molinaro \& Costa 2001; Vaz-Imbassahy \& Costa 2008; Costa 2010), but as a botanist she remains unknown in Brazil. As a collector her name is cited as M. Bandeira, M. C. Vaughan Bandeira, and, M. C. V. Bandeira. In such cases there is no clue as to her gender. A casual reader will never know that the author of the article is citing a female collector of historical impor- 


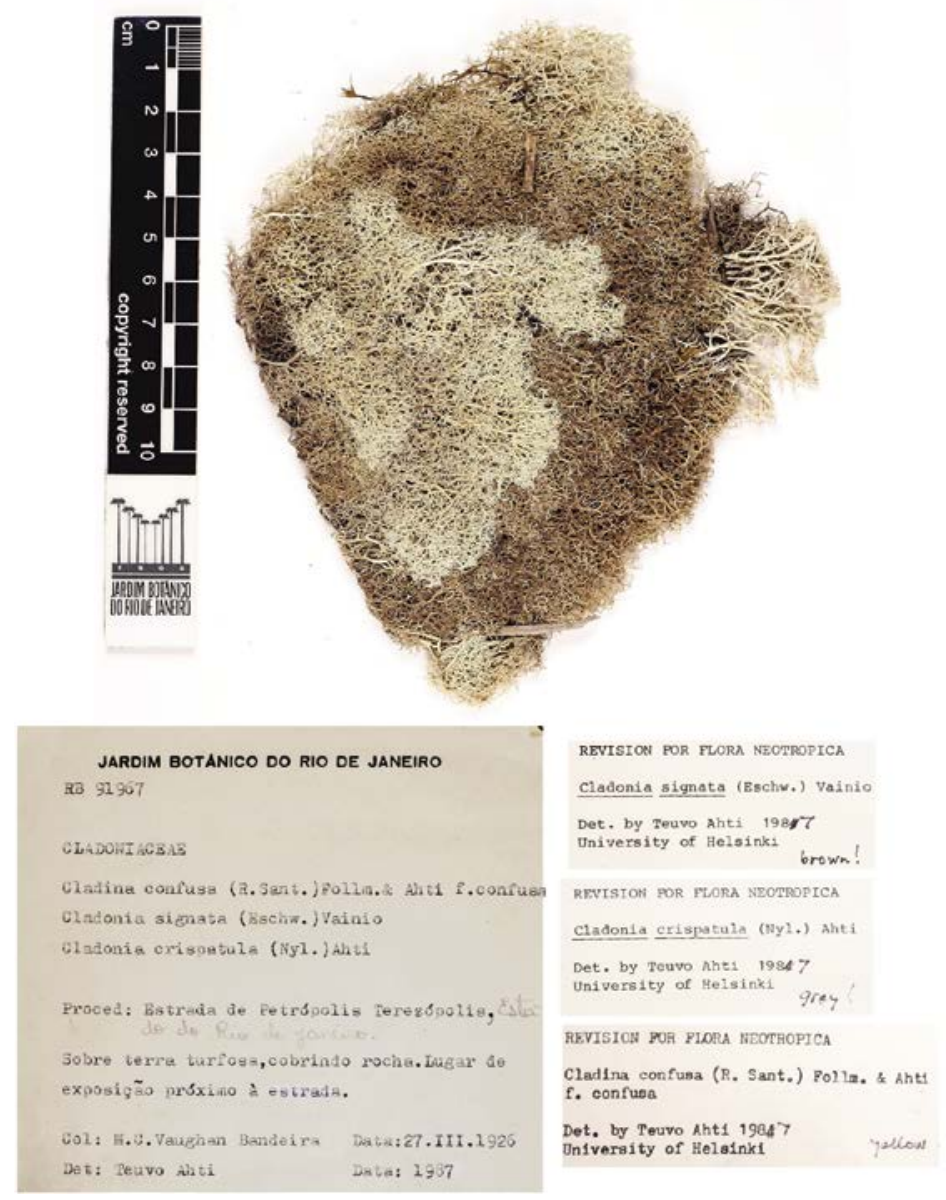

Fig. 6. Specimen of moss Dicranella guilleminiana (Mont.) Mitt. collected by Maria Bandeira (M. C. V. Bandeira 224, RB).

tance. She was one of the first woman botanists, if not the first, to ever collect mosses in Brazil. The fact that she never published a single paper certainly contributed a great deal to her present invisibility. She also collected with other botanists such as Adolfo Ducke (1876-1959) and João Geraldo Kuhlmann (1882-1958). In those cases the citations of these collections bury Bandeira's name in the standard abbreviation 'et al.'

In our opinion, Maria Bandeira deserves a place in the history of botany in Brazil because she was the first woman to be hired as a botanist by the Botanical Garden in Rio de Janeiro, she made important collections of mosses, fungi and lichens, besides the occasional angiosperms (Laureceae, grasses, etc.), and also because she was part of a greater network of women scientists who collaborated with each other and opened new opportunities to other women in later years. For almost a decade she worked with men (including Adolfo Ducke, Pacheco Leão and João Geraldo Kuhlmann) who admired and respected her, a noteworthy fact in an era when most women were second-class citizens and were denied leading positions in science. As evidence of her prestige among her peers, we mention that in 1930 she was a member of the editorial committee of Archivos do Jardim Botânico, the institutional research journal of the Botanical Garden in Rio. Needless to say, she was the only woman on the board at that time. 

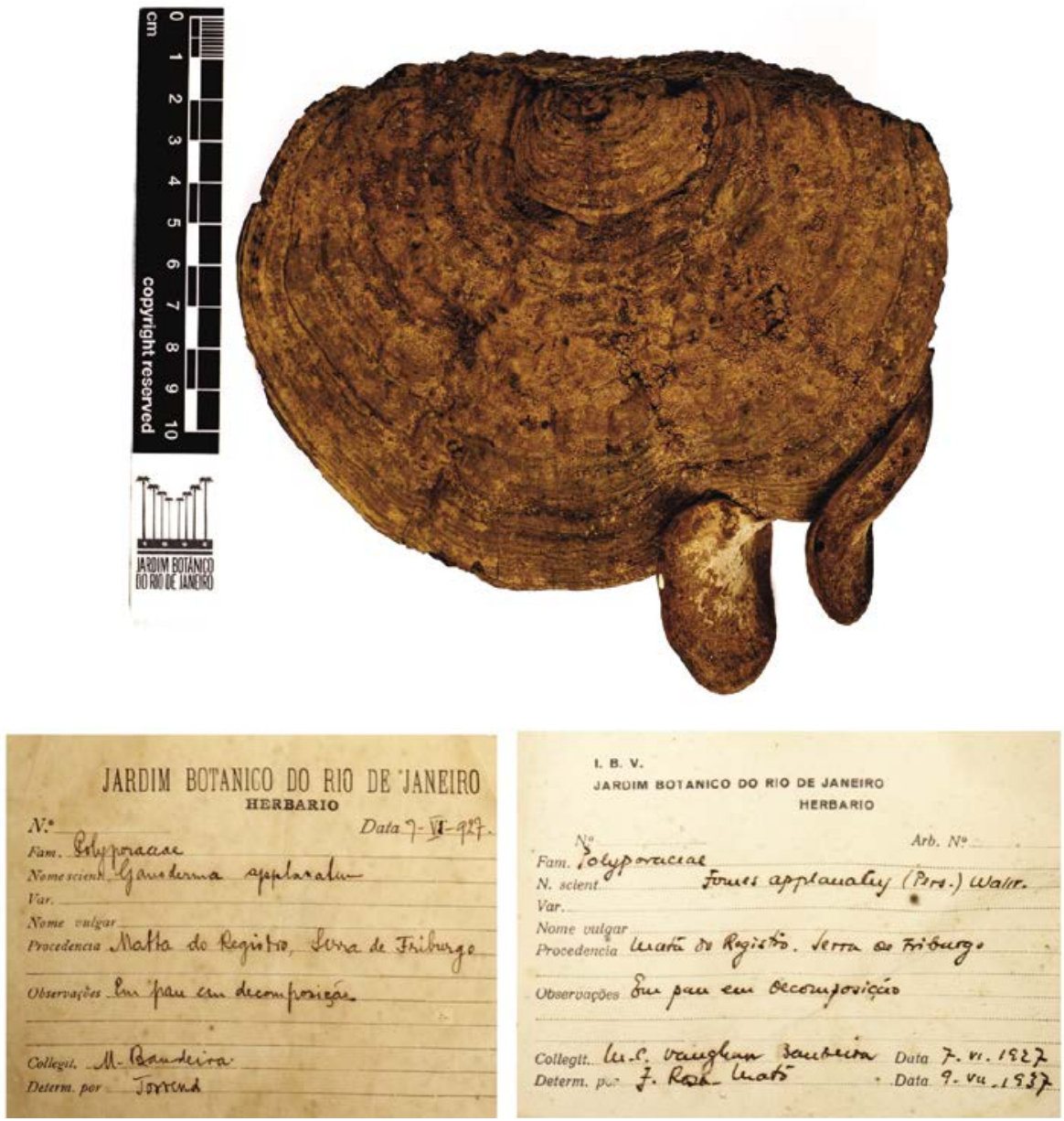

Fig. 7. Specimens of lichens Cladina confusa (R. Sant.) Follm. \& Ahti, Cladonia signata (Eschw.) Vain. and C. crispatula (Nyl.) Ahti collected by Maria Bandeira (M. C. V. Bandeira s.n., RB 91967).

More important, perhaps, is that Bandeira was part of a moment in the history of the Rio de Janeiro Botanical Garden when great botanists such as Ducke, Kuhlmann and others were publishing important contributions to the study of the Brazilian flora. She was part of the team, she was their contemporary - a colega, as Ducke frequently called her in his letters ${ }^{17}$. Bandeira's moss, fungi and lichen finds were an integral part of the Garden herbarium's scientific collection available for study

\footnotetext{
${ }^{17}$ Letter from A. Ducke to M. Bandeira, Rio de Janeiro, 13 Sept. 1930. Private archive of the Bandeira family, Rio de Janeiro, Brazil.
}

(Figs 6-8). The time when Bandeira worked at the Garden coincided with a moment when the Garden was trying to reach out to other similar research institutions and to broaden its scope. Bandeira was quite instrumental in that respect. Her letters to leading botanical scholars of the time helped to make the Garden more visible in the scientific world. Unfortunately, while the work of the male botanists grew in importance as time passed, hers, as a female collector, became almost invisible. Now we think the time has come to accord Maria Bandeira her rightful place among a group of botanists who worked together in the Rio de Janeiro Botanical Garden in the 1920s. 

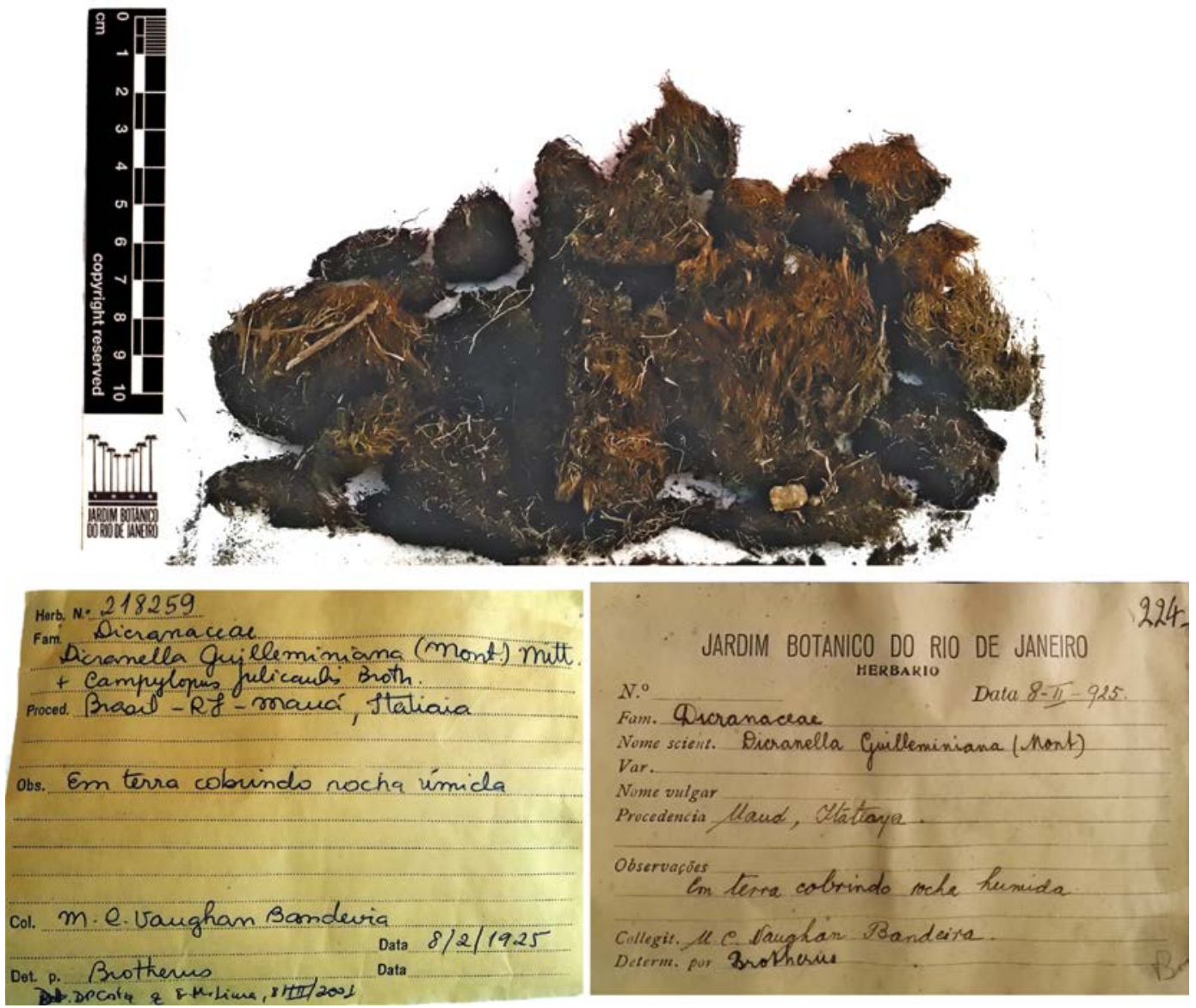

Fig. 8. Specimen of fungus Ganoderma applanatum (Pers.) Pat. collected by Maria Bandeira (M. C. V. Bandeira s.n., RB 218377).

\section{Closing REMARKS}

As stated above, the reasons behind Bandeira's decision to give up a professional career and enter a convent are beyond the scope of this simple account. Perhaps personality and past experiences led her to choose that path. However, it is almost shocking to realize that a highly intelligent woman who had climbed one of the highest peaks in Brazil (Itatiaia, ca 2,700 $\mathrm{m}$ a.s.1.) with no less a person than Agnes Chase at her side, descending 'with their skirts filled with specimens' (Henson 2003), voluntarily remained for sixty years behind thick convent walls, eating frugally, sleeping on two hard boards, spending long hours praying in the monastic choir, fasting frequently and keeping almost perpetual silence - in other words, living in self-denial. Indeed, an enigmatic personality, a mysterious woman, an extraordinarily generous human capable of giving herself entirely to an idealistic, mystic way of life.

Perhaps the true meaning of Maria Bandeira's gesture can only be grasped by those who cast off their prejudices and plumb the inner depths of their own souls.

ACKNOWLEDGEMENTS. We are grateful to the Bandeira family and the nuns from the Santa Teresa Convent in Rio for providing us with valuable information, the librarians and archivists of the institutions named in the text and footnotes for their kind assistance and sharing of information, and Dr. Denise Costa and Dr. Olga Yano for generously providing information on the literature of mosses. 


\section{REFERENCES}

Brazil [Federal Government] 1928. Diário Oficial da União. Ministério da Agricultura, Indústria e Comércio (19/04/1928, p. 10120). [28 Mai 2013]. http://www.jusbrasil.com.br/diarios/1928119/pg-48-secao-1-diario-oficialda-uniao-dou-de-19-04-1928.

Castro G. L. 1929. Relatório apresentado ao Presidente da República dos estados unidos do Brasil. Anno de 1927, p. 89. [28 Mai 2013]. Serviço de Informações do Ministério da Agricultura, Rio de Janeiro. http://brazil.crl.edu/bsd/ bsd/u2023/000001.html.

Costa D. P. 2010. Briófitas. In: R. C. Forzza, J. F. A. Baumgratz, C. E. M. Bicudo, A. A. A. Carvalho Jr., A. Costa, D. P. Costa, M. Hopkins, P. M. Leitman, L. G. Lohmann, L. C. Maia, G. Martinelli, M. Menezes, M. P. Morim, M. A. N. Coelho, A. L. Peixoto, J. R. Pirani, J. Prado, L. P. Queiroz, V. C. Souza, J. R. Stehmann, L. S. Sylvestre, B. M. T. WAlter \& D. ZAPPI (eds), Catálogo de plantas e fungos do Brasil. 1: 452-521 Andrea Jakobsson Estúdio \& Instituto de Pesquisas Jardim Botânico do Rio de Janeiro, Rio de Janeiro.

Gallian D. M. 1997. Madre Maria José de Jesus: no caminho da perfeição. Edição do autor, Gráfica Paulus, São Paulo.

Henson P. 2003. What Holds the Earth Together: Agnes Chase and American Agrostology. Journal of the History of Biology 36(3): 437-460.
Luizi-Ponzo A. P. \& BARTh O. M. 1999. Spore morphology of some Dicranaceae species (Bryophyta) from Brazil. Grana 38: 42-49.

Molinaro L. C. \& Costa D. P. 2001. Briófitas do arboreto do Jardim Botânico do Rio de Janeiro. Rodriguésia 52(8): 107-124.

Petitjean P. 2001. Miguel, Paul, Henri et les autres. In: A. A. P. Videira \& S. R. A. Salinas (eds), A cultura da física: contribuições em homenagem a Amelia Imperio Hamburger, pp. 59-94. Editora Livraria da Física, São Paulo.

Trebitsch M. 1995. Les réseaux scientifiques: Henri Laugier en politique avant la Seconde Guerre mondiale (1918-1939). In: J. L. Crémieux-Brilhac \& J. F. Picard (eds), Henri Laugier en son siècle, Cahiers pour l'histoire de la recherche, pp. 23-45. CNRS-Éditions, Paris.

Vatтimo-Gil I. \& Vattimo I. 1980. Bryophyta (Musci) do herbário do Jardim Botânico do Rio de Janeiro II. Rodriguesia 54: 257-267.

Vaz-Imbassahy T. F. \& Costa D. P. 2008. The Pilotrichaceae (Hookeriales) of Rio de Janeiro, Brazil. Bryologist 111: 551-575.

Yano O. 2008. Catálogo de Antóceros e Hepáticas Brasileiros: literatura original, basiônimo, localidade-tipo e distribuição geográfica. Boletim do Instituto de Botânica 19: 1-110. 